\title{
'Thrilling Empire': Indian History and Questions of Genre in Victorian Popular Fiction
}

\author{
Flaminia Nicora \\ Department of Foreign Languages, Literatures and Communication University of Bergamo -Italy \\ *Corresponding Author: flaminia.nicora@unibg.it
}

Copyright (C) 2013 Horizon Research Publishing All rights reserved.

\begin{abstract}
The article focuses on the features of a subgenre rather popular with the Victorians, neglected (although evoked) by major, canonic novelists. The Mutiny novel has been identified by recent criticism as one of the pieces of the mosaic in the construction of British identity. This model of identity supports the national imperialist vocation, extolling British qualities and representing historical events in mythical, stereotypical and racist fashion, according to clear, and closely monitored, ideological values. At the same time these novels offer fertile ground to explore the uncertainties and the contradictions that complicate the pattern, warning against any simplistic attitude towards Victorian Weltanschaaung. An interesting author in this regard is George Chesney, mostly known for his The Battle of Dorking or for his works about Indian administration. Chesney is the author of a Mutiny novel, The Dilemma (1876), that sets a plot typical of the sensational novel against the background of the Rebellion, revealing the powerful anxieties inherent the colonial adventure. Other novelists who wrote on the Rebellion (G. Henty, J.F. Fanthorne among them) are equally interesting to explore the ambiguities of identity construction.
\end{abstract}

Keywords Postcolonial, Mutiny Novel, Subgenre, Sensation Novel, Historical Novel, G.Chesney, National Identity, Victorian Literature, British Empire, India

\section{Introduction}

Victorian popular fiction's omnivorous appetite for themes and settings could not overlook imperial life and India in particular, the colony that most contributed through its 'literarization' (Booker, 1997:105) to shape colonial discourse.

The Indian rebellion of 1857, the 'Mutiny' as British contemporaries defined it, conjugated the interest for history with the immense curiosity that surrounded colonial life, proving to be a fecund and long lasting source of inspiration for many Victorian writers. i Recent critical studies have researched the Mutiny under different perspectives, exploring its place in the British imagination, in Victorian ideology and novel writing. ii Victorians like Hilda Gregg, novelist herself and critic, were quite aware of the literary impact of this historical episode in fiction. In her article "The Indian Mutiny in Fiction?", published in Blackwood's Magazine, in February 1897, Gregg provides the analysis of a certain number of novels dealing with the rebellion, foregrounding a few features that may help to understand the place of the episode in Victorian popular novel and also to face some questions about genre in Victorian popular fiction.

This article follows the path traced by Gregg, further exploring some of the same questions. In particular, it will address the issue of the popularity of Victorian novels staging the Mutiny, firstly considering their large and lasting readership; secondly analysing the genre features shared by the novels representing the rebellion. The formulaic structure at the basis of these novels, a trait that is recognized as a characteristic of popular fiction, allows to identify the 'Mutiny novel' as a subgenre based on a specific chronotope. This chronotope, although clearly identifiable, intersects with the dominant genres of Victorian popular fiction, such as melodrama, the sensation novel, juvenile literature. If literary quality fails most of the Mutiny novels, their value in term of cultural history is now acknowledged: subjectivity and the negotiation of ideologies, can be traced in this strand of popular fiction.

\section{The Rebellion and the Popular Imagination}

Writing at the end of the century, Hilda Gregg could easily be conscious of the extraordinary grip that the topic of the Rebellion exercised on "the popular imagination", in comparison to other historical events.iii The Indian uprising was crucial in changing the relationship between Britain and its most important colony, but its abruptness and its violence were essential ingredients in determining the interest of the media and the public's long lasting involvement (Brantlinger 1988). While the press and virtually all other available media immediately invaded the market provoking strong reactions in the public (the Mutiny inspired Music-hall songs, 
theatrical performances, ballads, cartoons, drawings, diaries, letters and reports of various kinds), the novel, as Gregg did not fail to observe, took some time before it started to exploit the topic of the Mutiny.

$<<$ That the Mutiny should loom large in English fiction does not, therefore, seem matter of surprise, but it appears somewhat strange to us who look back upon it to note the length of time which elapsed before its "Value" (we use the word in its dramatic sense) was perceived. Those were not days in which "shilling shockers?" dealing with the events of a projected campaign, and written, apparently, by persons endued with the spirit of prophecy, were brought out almost as soon as war was declared, and yet there were not wanting even at that time up-to-date writers who knew how to utilise the flowing tide of popular excitement for their own advantage. A glance at the columns of the newspapers of 1858 and 1859 will show the truth of this. [ ] Still we find no use made of the Mutiny in fiction >> (Gregg 1897:220).

Gregg reminds her audience that Mutiny novels are not "shilling shockers?" written for immediate consumption , but on the whole the critic's evaluation of the literary quality of novels concerned with the 1857 events is mostly negative.

This class of literature with which we are about to deal is strictly that which the librarians of the British Museum, with a paternal care for the moral welfare of their generation, withhold from the ordinary reader for the space of five years after its publication, in the faint hope that a portion, at least, of its deleterious influence may have evaporated during the interval.

Confining ourselves, then to books of this reprehensible nature, we are surprised to find how large a number of them demand our attention? (Gregg 1897:218).

Almost to Gregg's surprise, many different episodes of the Mutiny offered the backdrop for a proper strand of the historical novel, written both by Anglo-Indians, and by British metropolitan authors. Describing what already appeared to be an inexhaustible source of inspiration for a series of novels, Gregg foregrounds at least two of the characteristics that are usually attached to popular fiction: appeal to large numbers of readers and poor literary quality. In fact, the first survey of the fiction that stages the rebellion, insists on its "reprehensible nature? to the point that the critic ends her investigation expressing her wish that a major author, perhaps Kipling, might write a respectable novel on the topic: <<When Mr Rudyard Kipling's 搈 agnum opus? appears, may it deal with the Mutiny and may we be there to read it! $>>$ (Gregg 1897:231). At the same time the study recognizes the success of these fictional works in terms of the readers' approval, from adult to juvenile.

Albeit none of the novels on the rebellion was a best seller of the calibre of other novels of the 19th century, which could count various thousands of copies, their reputation was never in question. About fifty titles were published between 1859 and the end of the century. Some of them were first serialized and later were reprinted in a volume. A case in point is Robert Forrest' Eight Days, published on Cornhill Magazine (from July1890), or Henry S. Merriman's Flotsam, that came out on Longman's Magazine (1896, eight instalments), although they are not isolated examples. Several novelists were regular or occasional contributors to prominent magazines and reviews such as Blackwood's Magazine, Fraser's Magazine, Edinburgh Review, Bentley's Miscellany, The Union Jack, Boy's Own Magazine and more. Not all the authors were professional novelists or even writers. In some cases, their occasional articles concerned Indian or colonial questions of which they had developed field competence. In fact, the novels on the uprising have been written by a variety of authors, who can be broadly grouped as Anglo-Indian and metropolitan, at least until the end of the $19^{\text {th }}$ century. The first were mostly non professional writers, coming from the ranks of the army, or civil servants of the East India Company, who had often been personally involved into the war. Colonel Edward Money, Hugh Poyntz Malet, Philip Meadows Taylor, George Chesney, Robert Forrest, Preston Muddock, J.F. Fanthorne had been eyewitness of the events they later put into fiction. Some of them had attended Addiscombe Military Academy or the East India college (later Haileybury and Imperial Service College), where the East India Company trained its officers and its civil servants. They felt legitimated by their own firsthand knowledge of the uprising to bring their experiences and their assessment of the events on the page, although they chose fiction rather than history. In the preface to his novel, Robert Forrest declares that he writes with "the eagerness of an eyewitness of the events [to] explain everything that [he] is capable of explanation? J.F. Fanthorne shares the same anxiety to redress the false representation of the Mutiny that other novelists, in this case James Grant, who is the explicit target of his criticism, have made popular.

Metropolitan authors were mainly professional novelist, who exploited this topic together with many different others, addressing adult or juvenile publics, according to their vein or interests. We can mention George Henty, James Grant, Meadows Taylor, Flora Annie Steele, Henry Kingsley. Some of them were quite popular with the Victorian public, although not necessarily for their Mutiny novel. None of the major $19^{\text {th }}$ century writers has dealt explicitly with the rebellion, although its echo resonates in several novels. The Mutiny looms in C. Dickens A Tale of Two Cities, E. Braddon Lady Audley's Secret, W. Collins The Moonstone, R. Kipling Kim, but never comes to the forefront.

The quantity of reviews of individual novels and the articles on the narratives of the rebellion also testify the resonance of the Mutiny novels. The Athenaeum, the famous literary magazine, reviews twenty Mutiny novels between 1859 and 1914; Blackwood's Edinburgh Magazine, The Calcutta Review, The Saturday Review also devote space and attention to several novels featuring the rebellion.

In absence of more precise data on the number of copies printed, the popularity of these novel is documented by their presence in the catalogue of the circulating libraries of the time. The largest and by far the more influent on the reading public's tastes with its 25000 subscribers at the beginning of the 1890s (Griest 1971), Mudie's, is not the only library to 
offer ample demonstration of the general appreciation. Several novels on the Indian rebellion can be traced in Mudie's catalogue for decades after their publication since the 1860s. Only when more recent titles were available the oldest ones were eliminated. During the last decade of the century, the catalogue contained about ten titles out of the almost fifty works that had been published. Other circulating libraries adopt a similar policy, recognizing, but at the same time endorsing the commercial success of the novels concerned with the Indian rebellion. More evidence can be found in A Catalogue of Books in the General Subscription Circulating Library at Reading (1887) which lists Mutiny novels written by G. Lawrence, H. Malet, J. Grant, H. Kingsley, M. Taylor, G. Chesney, R. Sterndale.

Several novels were also available for purchase, often in deluxe editions, recommended amongst the Books for presents and prizes or mentioned in the Catalogue of Books of the best authors in ornamental bindings in Mudie's Select Library. The volumes were advertised as "carefully selected" and "well adapted for Drawing-Room Tables and Gentlemen's Libraries, and for Wedding and Birthday Presents, and School and College Prizes? In short, readers were encouraged to appreciated these works, which conjugated entertainment with the patriotic and ethical values supported by Mudie's and guaranteed by its extremely attentive editorial policy.

The long lasting success of the novels concerned with the rebellion during the Victorian age is clearly due to the fact that they are generally supportive of the national imperialist vocation of the country, extolling British qualities and shaping historical events into a mythographic construction of personal and national heroism. Steven Attridge (2003) explains the revival of the topic of the Mutiny at the turn of the century with the need for positive identity models as an antidote to the anxiety brought by the difficulties of the Empire and the long Boer war. Gregg is very clearly in tune with the ideological turn shown by the majority of these novels, to the point that she harshly condemns the works that may occasionally and partially discard the monolithic representation of patriotism. iv Despite this, she is rather skeptical of the literary quality of these novels. Her assessment reflects the widening divide that came to mark the difference between high literature and popular literature between the middle and the end of the $19^{\text {th }}$ century: the inclination towards naturalistic, psychological realism and later the modernist problematization of artistic language was identified as the distinctive quality of high literature; by contrast, the development of subgenres that relied on formulaic structures, stock characters and exploited specific ingredients such as mystery, sensationalism, romance, became increasingly associated with low-brow popular literature, whose circulation increased with the emergence of the "instant books" inspired by topical events and the cheap "penny dreadful"

\section{Genre Questions: Ideology and Ambiguities}

Although based on historical facts and seemingly realistic, the novels on the rebellion have a strong penchant for romance and in some case for sensationalism, which explains both their popularity with the Victorians and, later, their exclusion from the canon of high literature. The recent critical attention devoted to these novels is addressed to their cultural value, no less than to their genre features, more complex and ambiguous than it may seem at first sight.

The analysis of the corpus of novels concerned with the Indian uprising makes evident that they share more than an interest in the representation of a particular episode of colonial history. In fact, thematic consistency goes together with a system of invariants that rests on a specific chronotope, in which "spatial and temporal indicators are fused into one carefully thought-out, concrete whole. [ ] The chronotope in literature has an intrinsic generic significance" Bachtin quoted in Holquist 1999:85). The particular intersection between realistic temporal and spatial elements, drawn from an established repertoire and articulated in a series of narrative invariants, defines a recurrent chronotope, on which rests the possibility to recognize a proper subgenre of the historical novel. This subgenre could be referred to as the 'Mutiny novel'.v It is precisely as a rhetorical structure that the chronotope of the Mutiny novel plays a significant role in the Victorian episteme. Therefore, it is the articulation of genre, rather than of theme, that may explains the nuances of the construction of British identity.vi

The main constant sequences of the chronotope identified by my research are the following: 1) a description of the narrator's or the protagonists life conditions, usually back in Great Britain; 2) a description of life in the colonial station before the rebellion; 3 ) arrivals of new British members of the colonial community (sometimes relatives of the protagonists, love rivals of residents); 4) hunting scenes; 5) outbreak of the revolt and the residents' resistance to the siege of the native rebellious troops; 6) arrival of British army to relieve the characters from siege; 7) revenge taken on the natives; 8) restoration of order and weddings of the young couples; 9) return to Great Britain.

Mutiny novels do not usually exploit all the sequences, but almost always hinge on the most relevant and extended one, the narration of the siege and the resistance of the British residents of a particular station, contrasted with the previous or the recovered normality of ordinary life. The focus on one or more episodes of the revolt (time), restricts the possible choice of the setting (space) to the area where the Mutiny took place. Even when the action moves to Great Britain, it is the relation between the metropolitan centre and the colonial periphery established by the events of the Mutiny, or in other words the chronotope itself, that produces meaning. The persistence of an analogous structure in the different novels allows the reader to recognize the subgenre and to identify the representational code that backs the construction of the myth of national heroism epitomized by the Indian rebellion. 
Even if the Mutiny novels are not turnpagers in a strict sense, the plot is the pivot of the narrative. It mostly follows a linear chronological development which is modelled on the history of the rebellion, but, at the same time, is always intersected with the fictional characters' love stories. Marriage sanctions the restoration of order, conjugating the private and the public grounds. Historical figures are always mentioned, but the protagonists are fictional characters, mainly belonging to the middle or upper-middle class. The love story and the rebellion are completely entangled: the resistance to the natives works as a test that unveils the true qualities of man and women. Usually, the ladies who had been attracted by brilliant but unworthy suitors proceed to marriage with the more reliable partners. The same is true for the male protagonists, officers or young soldiers whose career has been boosted by the rebellion, thanks to their courage and their attachment to patriotic values.

Although a very specific blueprint in itself, the chronotope of the Mutiny novels exploits several narrative modes, from realistic and Bildungsroman concerns, to adventurous and sentimental romance, together with occasional incursions into sensational fiction and gothic. ${ }^{\text {vii }}$ Thus, the formulaic structure of these particular popular novels, offers a certain variety and even a certain complexity. The inclusion of formal features of other subgenres works sometimes to strengthen, but sometimes to partially question the stereotyped construction of identity that is at the core of Mutiny novels. In particular the Mutiny novels balance mimetic and aestheticizing drives, never decisively inclining towards one at the expense of the other. Realism never disrupts the expected plot development, sinks into characters psychology or calls for multiple perspectives. Nor does it give way to naturalistic, detailed analysis of the social features of the colonial world. On the other hand, fantasy and romance never risk discarding the role of the colonial novel as a vehicle of reliable information about the Empire. Realism, romance, adventure and history systematically come together in a precarious blend whose main objective seems that to produce a consolatory but credible happy ending, which gives the impression to spring directly from reality itself. This balance depends upon the juxtaposition of different genres, fictional and even non-fictional (i.e. history writing, political discourses, geographic reports)

According to Chakravarty, some historical and literary discourses unfold in a parallel manner and exchange rhetorical strategies. The historiography of the rebellion exploits the rhetoric patterns of romance and melodrama, supporting the general conviction that reality itself confirms the triumph of the 'master race', the incontrovertible happy ending of the revolt (at least from the British point of view) and the records of many heroic deeds. J. Muddock in his novel The Great White Hand (1896) explicitly declares that the Mutiny had features that are usually found in fiction rather than in reality: ?if the) dramatic situations in which my characters become involved are overstrained and improbable I shall claim the authority of history that the thrilling times of the Revolt were rich in situations so sensational, so dramatic, so tragic and pathetic that they put fiction in the shade. The bare ungarnished story of the Rising is in itself one if the most sensational records the world has ever known.?(Muddock quoted in Chakravarty 2005:78)

The overlap of "documentary realism and colonial romance" Chakravarty 2005:72) is crucial in the structuring the Mutiny novel's construction of identity and its ideological underlay. The novels on the rebellion display realistic elements that fulfil the need to know about the colonial world and its history, but romance controls the pattern of the relation between the metropolitan and the colonial world. Verisimilitude and plausibility naturalize the ideological construction. Hence, the success of the subgenre in popularizing it, while performing a recognized educational role.

\section{Conclusion}

In our view, the generic instability of the Mutiny novel reveals that the subgenre cannot be read as a simplistic outcome of the social and moral order cherished by the middle class and expressed by the multifaceted forms of Victorian melodrama.

On the one hand, the macrotext of novels on the rebellion gives voice to the "moral fantasy" invoked by the middle class as an antidote to the insecurity raised by the rapidly changing times, and reflects what P. Brooks (1985) calls the 'melodramatic imagination'. viii The melodramatic element remains the common denominator of the genre's episteme. The Mutiny novels' "outcome turns less on the triumph of virtue than on making the world morally legible, spelling out its ethical forces and imperatives in large and bold letters?(P.Brooks 1985:43). In fact, the novels hinge on a polarization of values that culminates in the triumph of what is socially acknowledged as good and moral. We may mention E. Money's The Wife and the Ward (1859) as a case in point. This novel has a very fragmented plot that, as a contemporary reviewer remarks, leaves the reader "with the feeling that it is not a unity. [...] In fact the volume contains two books. The first is the story of Life in an Indian Cantonment or the Wife, and the second may be termed the Nana Sahib or the Ward?(Anonymous 1859:xxvi). Despite the patchy plot and the fact that the novel's ending registers a number of failures -apparently diverging from the chronotope of the Mutiny novel - the dead and the defeated are clearly the real heroes, who embody the right moral values. In this case, the public and the private spheres do not reconcile in history, but in the melodramatic structure, which proves to be the glue that keeps together what is otherwise split.

On the other hand, it is worth noting that in some Mutiny novels the equilibrium reached by the various generic components may sound particularly precarious and encourage readings that focus on the uncertainties and contradictions of the Victorian Weltanschauung (Nicora 2007, Herbert 2008). 
Herbert's recent study is particularly critic of postcolonial readings of Mutiny novels that in his view underrate the complexity of Victorian thought. In fact, we may once more go back to Gregg's article to find traces of some fissures in the construction of identity inscribed in Mutiny novels and to measure their perception. Nisbet is openly criticised by Gregg as anti-patriotic, but other novelists are blamed because they -unnecessarily according to Gregg - focus on characters who indulged to unworthy behaviour, spoiling the tale of heroism and self-sacrifice associated to the Mutiny by hegemonic discourses (226-228). We may assume that neither the representations of the rebellion, nor the readers' responses were probably homogeneous. Part of the audience probably shared Gregg's strong reactions; others were attracted by the novelists' doubts and concerns on issues as the political responsibility for the breaking out of the rebellion, or the racial or social constructions of identity. For example, the sensationalist drive of some Mutiny novels exposes some of the anxieties of Victorian society, foregrounding the role played by genre in identity construction.

A case in point is George Chesney's The Dilemma whose plot conjugates the chronotope of the Mutiny novel with traits of the sensational novel. The Mutiny and bigamy are represented as parallel explosions of destructive forces that challenge the social order. While the Indian rebellion can be repressed, bigamy proves to be an even more insidious transgression, which only the suicide of the heroine may tame. Disguise, mystery, passions expose the dark side of the British construction of identity. The perfect heroine forged by the Mutiny demonstrates indeed morally very frail: she marries the wrong man, a villain who condemns her to poverty and misery. Even back in Great Britain, social roles sounds ambiguous to the positive hero, Yorke, who strives to discover who hides behind a respectable facade. The critique that can be found in the novel does not concerns colonial matters, but rather the unconscious drives that move the individuals. The vigour in the ideological closure of melodrama and the triumph of order in The Dilemma is proportional to the violence of the threat to the moral and social order encompassed by the novel. The generic structure of the Mutiny novel, strained by the sensationalist features, challenges the meaning that are usually conveyed by the form, perhaps even beyond the author's control. Chesney's novel is not an isolated examples. More investigation of the question of genre at stake in the Mutiny novel will certainly add to our understanding of Victorian popular culture.

\section{REFERENCES}

[1] Anonymous (1859), "Critical Notices of Works on India and the East Published during the Quarter? The Calcutta Review, June, n.LXIV, pp.xxv-xxxiii.

[2] Attridge S. (2003), Nationalism, Imperialism and Identity in late Victorian Culture, Basingstoke, Palgrave.
[3] Bachtin M., "Forms of Time and of the Chronotope in the Novel? in Holquist M. (ed.) (1999), The Dialogic Imagination. Four Essays. Austin: University of Texas Press [1st ed.: 1981]

[4] Booker K. (1997), Colonial Power, Colonial Texts: India in the Modern British Novel, Michigan U.P.

[5] Brantliger P. (1988), Rule of Darkness, Ithaca and London: Cornell U.P.

[6] Brooks P. (1985), The Melodramatic Imagination. Balzac, Henry James, Melodrama, and the Mode of Excess, New York: Columbia University Press. [1st ed.: 1976].

[7] Chakravarty G. (2005), The Indian Mutiny and the British Imagination, Cambridge: Cambridge U.P.

[8] Gregg H. (1897), "The Indian Mutiny in Fiction? Blackwood' s Edinburgh Magazine, Feb. 1897, pp.218-232.

[9] Griest G. (1971), Mudie's Circulating Libraries and the Victorian Novel, Newton Abbot.

[10] Herbert C. (2008), War of No Pity. The Indian Mutiny and Victorian Trauma, Princeton N.J.: Princeton U. P.

[11] Nicora F. (2007), "The crack in the cornerstone. Victorian identity conflicts and the representation of the Sepoy Mutiny in metropolitan and Anglo-Indian novels? in Teuli?G. (ed.), Cahiers Victoriens et Edouardiens, Oct. 2007, n.66, (2009), Montpellier, Presses Universitaires de la Mediterranée,, pp.257-272.

[12] Nicora F. (2009), The Mutiny Novel. Literary Responses to 1857 Rebellion, Delhi: Prestige Books.

[13] Paxton N., "Mobilizing Chivalry. Rape in Flora Annie Steel On the Face of the Waters (1896) and Other British Novels on the Indian Uprising of 1857? in Leah Harman B. and Meyer S. (1996), The New Twentieth Century. Feminist Reading of Underread Victorian Novels, New York and London: Garland Publishing.

i The rebellion is still staged into contemporary novels $\left(20^{\text {th }}\right.$ and $21^{\text {st }}$ century) that indulge on romance elements such as love story or adventure incorporated in the historical setting of the rebellion. Other novel display a satirical, corrosive attitude towards mythographic interpretations of the Mutiny, Among the best sellers: John Master's Nightrunners of Bengal (1951) and Margaret Kaye's Shadow of the Moon (1957), both still in print, and George MacDonald Fraser's Flashman and the Great Game (1975). Some novel have been prize winners, such as Katharine Gordon's Emerald Peacock (1979) and Valerie Fitzgerald's Zemindar (1981), both awarded the FosterGrant Romantic Novel of the year Award, a prize devoted to romantic fiction. Winner of prestigious Booker Prize was James Farrell's The Siege of Krishnapur (1973). One of the most recent Mutiny novels is Julian Rathbone's The Mutiny. A Novel (2007)

ii Among most recent studies Chakravarty G. (2005); Herbert C (2008); Nicora F. (2009).

iii $<<$ Of all the great events of this century, as they are reflected in fiction, the Indian Mutiny has taken the firmest hold on the popular imagination. Leaving out of sight the long wars with France, which are dear, probably on account of their many sea-fights, to the heart of writers for boys ... we must go back to the Jacobite outbreak of 1745 to find an epoch in English history, the characters and scenes of which appeal with equal vividness to the writers and readers of romance. $>$ (Gregg 1897:218).

iv See her criticism of Hume Nisbet's The Queen's Desire(1893), charged of the "fault of want of patriotism": "Anglo-Indian society is, and no doubt has always been, very far from being an assemblage of immaculate angels, unfortunately; but we refuse to believe that in 1857 all its members were either unscrupulous fanatics or avaricious flirts and lady-killers, as he would fain assure us. [...] We know also that the chief of those to whom England looked, and not in vain, at that dark hour, only exhibited in the red glare of danger the self-sacrifice and the devotion to duty which had been their daily rule for years." (Gregg 1897:224)

v For a more detailed discussion see Nicora 2009, ch. 2. 
vi For a discussion of the Bachtinian chronotope of the chivalric romance traceable in some novels on the Indian rebellion see Paxton 1996.

vii Even postmodern Mutiny novels such as J.Farrell's The Siege of Krishnapur, highlight the structure of the chronotope through formal parody.

viii According to Brooks $(2005: 14)$ the 'melodramatic imagination' is the answer $19^{\text {th }}$ century Europe produced to fill the void left "by the final liquidation of the traditional Sacred". The melodramatic element in it various literary forms expresses the collective need to redefine the meaning of signs. 